\title{
A nyelv nyálkahártya és mirigyek innervációjának változása korai és késői kísérletes diabetes mellitusban
}

\author{
DR. KISPÉLYI BARBARA*, DR. ALTDORFER KÁROLY*, DR. FEHÉR ERZSÉBET**
}

\begin{abstract}
A nyelv nyálkahártya és mirigyek innervációjának változása korai és késői kísérletes diabetes mellitusban. Különböző szervekben egyes neuropeptideket tartalmazó idegrostok és immunkompetens sejtek mennyisége megváltozik diabetes mellitusban (DM). Jelen munkánkban kísérletes DM során a nyelv nyálkahártyában és annak mirigyeiben lévő idegelemek változásait vizsgáltuk immunhisztokémai módszerrel. Két héttel a DM kialakulása után minden általunk vizsgált neuropeptid tartalmú idegrost mennyisége szignifikánsan megemelkedett mind a nyálkahártyában, mind a mucinózus és szerózus mirigyekben. Az immunkompetens gyulladásos sejtek (limfocita, plazmasejt és hízósejt) száma is szignifikánsan megnőtt. Ezen sejtek egy része szintén pozitív reakciót mutatott $P$ anyagra és neuropeptid $Y$-ra. Egyes esetben a P-anyag pozitív idegrostok nagyon közeli kapcsolatban figyelhetők meg a P immunreaktív immunsejtek mellett. Négy héttel a DM kezelés után az immunjelzett idegrostok mennyisége lecsökkent a kéthetes kezeléshez képest, de a peripherin jelzett idegrostok mennyisége még így is magasabb, mint a kontroll állatban. Az immunsejtek és idegrostok közeli kapcsolata jelentős szerepet játszhat a nyelv nyálkahártya és mirigyek múködésének, homeosztázisának fenntartásában, a gyulladás kialakulásában és eliminálásában.
\end{abstract}

Kulcsszavak: P anyag, Neuropeptid $\mathrm{Y}$, nyelv nyálkahártya, neuroimmunomoduláció

A diabetes mellitus (DM) kóros anyagcserével és hiperglikémiával járó szindróma, a világ lakosságának szignifikáns részét érinti. A legutóbbi epidemiológiai vizsgálatok kimutatták, hogy 2011-ben a világon több mint 360 millió ember szenved DM-ben, és ez a szám az előrejelzések alapján 2030-ra elérheti az 532 milliót is [10]. A betegség hosszan tartó fennállása számos olyan tünettel jár (például hiperglikémia, retinopátia, nefropátia), ami megváltoztatja az életminőséget. Az erős fájdalom miatt különösen kellemetlen a cukorbetegek neuropátiájának szerepe. Diabeteses betegek gondozása során a gyakorló orvosok gyakran találkoznak különböző fog- és szájpanaszokkal. Az utóbbi évek statisztikai vizsgálatai megállapították, hogy a diabetes mellitusszal összefüggésben számos szájbetegség gyakrabban fordul elő: glossitis [2, 42], paradontitis, szájégés és az ízlelés zavara, leukoplakia, lichen oris planus és tumorok [29, 34, 41], valamint megemelkedik a szájüregi gombás fertőzések száma is [4]. Az objektív tünetek közül gyakori a diffúz eritéma, különösen a nyelven [43]. A nyelv megnagyobbodott, sok esetekben fehéresen bevont, Candida albicans fertőzés jeleként. A diabeteses betegek szájüregi tumorának lokalizációját vizsgálva kimutatták, hogy a nyelvdaganatban $(19,6 \%)$ és ajakdaganatban $(23,2 \%)$ szenvedő betegek száma a legmagasabb [40]. Albrecht és munkatársai [2] szerint a legtöbb leukoplakiás eset a diabeteses anyagcsere- zavar manifesztálódását követő második évben, gyakrabban az inzulinnal kezelt cukorbetegekben figyelhető meg. Az akut hiperglikémia következtében csökken a nyálban lévő mucin- és glükózkoncentráció, károsodik az antibakteriális anyagok mennyisége. Nagy számú beteganyagon kimutatták, hogy a malignus tumorok kialakulása szignifikánsan nagyobb a dohányzó cukros betegeknél [4]. Számos vizsgálat foglalkozik a diabetes gyulladásban és a sebgyógyulásban betöltött szerepével is [14, 32].

Az idegrendszer patológiás körülmények között nemcsak a gyulladás kezdeményezésében és fenntartásában játszik szerepet, hanem annak csökkentésében és eliminálásában is. A neuropeptideknek különösen nagy szerepet tulajdonítanak ebben a folyamatban. Az idegrendszer és immunrendszer mindkét irányú kapcsolatában különböző anyagok vesznek részt: neurotranszmitterek, neuropeptidek és citokinek. Gyulladás hatására ezen anyagok mindkét rendszer sejtjeiből (ideg-, immunsejtek) felszabadulhatnak és befolyásolják a gyulladást. Az immunrendszer szabályozásában legjelentősebb az érző idegrostokból felszabaduló Substance $\mathrm{P}(\mathrm{SP})$, calcitonin gene-related peptid (CGRP), valamint a lokális idegelemekből felszabaduló vasoaktív intesztinalis peptid (VIP) és a neuropeptid Y (NPY). Gyulladás hatására ezen neuropeptidek mennyisége megemelkedik, és hatásukra fokozódik a gyulladásos 
sejtek számának növekedése, különösen a hízósejteké, így hatásukra fokozódik az erek permeábilitása is [26]. Kísérletes DM-vizsgálatok is alátámasztották, hogy a korai streptozotocin DM (StDM) hatására a gyulladásos sejtek és az idegrostok száma megemelkedik [5, 11, 16], míg 14 nappal a kezelés után csökken a gyulladás és a plazma-extravazáció, és degenerált idegrostok jelennek meg a különböző szervekben [27, 28, 31]. Számos vizsgálat foglalkozik a szájüregi képletek vérellátásának változásával DM-ben [20,30]. Ugyanakkor csak nagyon kevés közlemény foglalkozik a nyelv nyálkahártya és nyálmirigyek idegelemeinek és immunsejtjeinek kvantitatív elemzésével.

Az előző vizsgálataink megállapították, hogy egyes neuropeptideket (SP, NPY) tartalmazó idegrostok és immunkompetens sejtek mennyisége szignifikánsan megemelkedett DM-ben az ízlelőbimbókban. Arra a kérdésre azonban nem kaptunk egyértelmű választ, hogy ez a változás az összes idegrostra vonatkozik-e. Továbbá nem vizsgáltuk a nyelvben lévő mirigyek beidegzésének változását. Ezért ezen munkánkban a korábban használt primér szérumok mellett peripherin (PER) antitesttel is vizsgáltuk a nyelv nyálkahártya és mirigyek innervációját. A peripherin a perifériás idegrendszerben lévő axonok neurofilamentumainak alegysége [44] és olyan panneurális (összes idegrost) jelző, amely az állati és humán perifériás idegek kimutatására alkalmas [19].

\section{Anyag és módszer}

Az idegelemek vizsgálatára kísérleteinket 30 darab, 120-150 g testsúlyú, hím albínó Wistar patkányon végeztük. Az állatkísérletek megfelelnek a „Revised Guide for the Care and Use of Laboratory Animals"-nek (ILAR 1996) és a Magyar Állatvédő Törvénynek (1998, Magyarország), valamint a Semmelweis Egyetem Etikai Bizottsága is engedélyezte ezeket. A diabetes mellitus kiváltásához az állat farki vénájába egyszer $65 \mathrm{mg} / \mathrm{test}$ tömeg kg Streptozotocint (Zanosar, Upjohn Company, Kalamazoo Ml 49001, USA) adtunk. A kontroll állatok $0,25 \mathrm{ml}$ fiziológiás só oldatot kaptak. A DM kialakulását a testtömeg csökkenésből, polyureából és glukózureából állapítottuk meg. A farki vénából vett vércukorszint $>16 \mathrm{mmol} / \mathrm{I}$ esetén az állatot cukorbetegnek nyilvánítottuk. A kontroll állatok (10 db) ugyanolyan súlyúak voltak, mint a vizsgálat kezdetén a diabeteses csoport. A streptozotocin hatását 2 és 4 hét után vizsgáltuk. $2(10 \mathrm{db})$ és $4(10 \mathrm{db})$ héttel a kezelés után az állatokat véglegesen elaltattuk és perfundáltuk. Kivettük a nyelvgyököt, majd fagyasztó mikrotómmal metszeteket készítettünk.

A kivett mintákat fixáltuk, majd a primer szérummal való inkubálás után avidin-biotin-komplex segítségével peroxidáz reakciót végeztünk. Primer szérumok: a korábban használt SP, VIP, NPY, CGRP, tumor nekrózis faktor $\alpha$ (TNF- $\alpha$ ), nukleár faktor KB (NF-kB) mellett az összes idegrost kimutatására egér monoklonális peri- pherin antitestet is használtunk ( $5 \mathrm{db}$ ) (Novo Castra, katalógus szám: P21935). Az anyagok egy részéből elektronmikroszkópos metszeteket is készítettünk, ahol az idegrostokat és az immunkompetens sejteket analizáltuk, valamint vizsgáltuk azok morfológiai kapcsolatait.

A jelzett idegrostok kimutatására avidin-biotin-peroxidáz (Vectastain ABC, Vector Laboratories, Peterborough, UK) technikát (1 órára), valamint diamino-benzidint (DAB Vector, 0,025\%, 3,3-diamino-benzidin, $0,0015 \% \mathrm{H}_{2} \mathrm{O}_{2}, 0,05 \mathrm{M}$ Tris- $\mathrm{HCl}$ puffer, $\mathrm{pH}=7,5$ ) alkalmaztunk 8-10 percre. Nikkellel intenzifikáltunk, majd a végén a metszeteket a zselatinozott tárgylemezekre terítve Depex-szel fedtük le.

A hízósejtek vizualizálásához a 0,1\%-os toluidinkék festéket (Sigma) vagy hisztaminellenes primer antiszérumot használtunk.

A fénymikroszkópos metszeteken megszámoltuk a különböző immunjelzett képleteket, majd statisztikailag értékeltük. Az immunreaktív (IR) idegrostokat 15$2000 \mu \mathrm{m}^{2}$ szövet területen számoltuk meg és a kapott eredményeket egységnyi területre $\left(100 \mu \mathrm{m}^{2}\right)$ vonatkoztattuk. A számoláshoz az egész metszetet vizsgáltuk fénymikroszkóppal 40 szeres nagyításban. Minden egyes vizsgált anyagból kb. 15-25 fényképet készítettünk, majd digitalizáltuk és számítógépes szoftverrel (IMAN (béta) 2,0 MFA, Budapest, Hungary) analizáltuk.

\section{Statisztikai módszer}

Az eredmények statisztikai értékeléséhez két minta esetén a Student-féle kétmintás t-próbát, több minta összehasonlítása esetén a variancia analízist (ANOVA) használtuk post hoc Bonferroni és páratlan Student-féle kétmintás t-próba összehasonlításokkal. A $p<0,05$ esetén az eredményt szignifikánsnak tekintettük.

\section{Eredmények}

Az IR idegrostok a patkány nyelvgyök minden rétegében megtalálhatók különböző mennyiségben. Néhány IR rost a mucinózus és a szerózus mirigyvégkamrák (Weber mirigy) körül is láthatók (1., 2., 3. ábrák). Az IR idegrostok föleg a hámban és a hám alatt találhatók (4., 5., 6. ábrák). Nagyon kevés hízósejt található ezen metszetekben, és hízósejt és IR idegrost kapcsolatot ( $3 \mu \mathrm{m}$-en belül) szintén ritkán tudtuk megfigyelni.

Diabetes mellitusban az IR idegrostok mennyisége megváltozott a kontrollhoz képest a nyelvgyökben. Két héttel a diabetes mellitus kialakulása után az IR idegrostok száma szignifikánsan megemelkedett. Nagyon sürü SP és PER IR idegrost-hálózatot találtunk a papilla vallatae subepithelialis területén és magában a hámban is (5. ábra). Egyes metszetben az IR idegsejtek száma is megemelkedett. A mucinózus mirigyvégkamrák körül is emelkedett az IR idegrostok mennyisége (2. ábra).

Azonban négyhetes diabetes esetén minden általunk 
vizsgált IR idegrost száma csökkent a nyelv összterületén, mennyiségük hasonló a kontroll állatokhoz viszonyítva. A SP és NPY IR idegrostok mennyisége még kevesebb, mint a kontroll nyelvben. A PER pozitív idegrostok mennyiségének változását mutatja a diagram a nyelv nyálkahártyájában és annak mirigyeiben (7. ábra). $A$ változás hasonlóan szignifikáns, mint a korábban vizsgált SP és NPY IR idegrostok változása. A SP, NPY és TH IR idegrostok vastagsága láthatóan megnövekedett.

Steptozotocinnal való kezelés után a nyelv lamina propria területe diffúzan infiltrálódott gyulladásos sejtekkel (limfociták, plazmasejtek és hízósejtek). Toluidinkékkel való festés kimutatta, hogy a nyelvgyök minden rétegében találhatók hízósejtek. A gyulladás területén az immunkompetens sejtszám-emelkedés mellett néhány sejt immunreaktivitást is mutatott SP-re és NPYra (5. ábra). A sejtek egy része kicsi, kerek 6-10 mm nagyságú sejt (limfociták), más része nagy, ovális, 1520 mm nagyságú (plazmasejtek valamint hízósejtek) sejt. Kéthetes diabeteses állatoknál a hízósejtek száma szignifikánsan megnövekedett $(p<0,05)$ a nyelv összterületét figyelembe véve. Legnagyobb mennyiségük azonban közvetlenül a hám alatt a lamina propriaban figyelhető meg, ezen belül is föleg az erek körül. Az IR idegrostok és a hízósejtek közötti kapcsolatok mennyisége szignifikánsan megemelkedett, különösen a SP pozitív idegrost-hízósejt kapcsolata, ahol a növekedés még szignifikánsabb $(p<0,01)$ volt (8. ábra).

\section{Megbeszélés}

Hosszan tartó hiperglikémia hatására károsodik a szájüreg nyálkahártyája és csökken a betegek nyáltermelése. Gyakran a nyál összetételében is változás alakul ki, következményként különböző szájüregi fertőzések léphetnek fel és csökken az ízérzés is [6, 29].

A neuropeptid tartalmú idegrostok mennyisége és lokalizációja megváltozik diabetes hatására, melyet számos szerző különböző szövetben és speciesben demonstrált, beleértve a gasztrointesztinális traktust, bőrt, ereket, a központi és a perifériás idegrendszert. A leírt elváltozások a peptid tartalmú idegrostok mennyiségére vonatkozva eltérőek [23, 24, 27]. Az adott szövet beidegzésétől és funkciós sajátosságaitól függően a neuropeptidek szintje és az IR idegrostok mennyisége növekedett, csökkent vagy nem változott [1, 39, 42]. A korai kísérletes DM-ben a gyulladásos folyamatok hatására a SP és NPY IR idegrostok száma megemelkedik, míg hosszan tartó betegség hatására szignifikánsan csökken a nyelv minden rétegében [5, 25], hasonlóan változik a PER IR idegrostok mennyisége is. $A$ bőr beidegzésében résztvevő CGRP és protein gene product (PGP 9,5) IR idegrostok száma hosszan tartó betegség hatására szignifikánsan csökkent [9]. A nyálmirigyek beidegzésében bekövetkezett változások hatással vannak a nyáltermelésre. SP növeli a nyál-

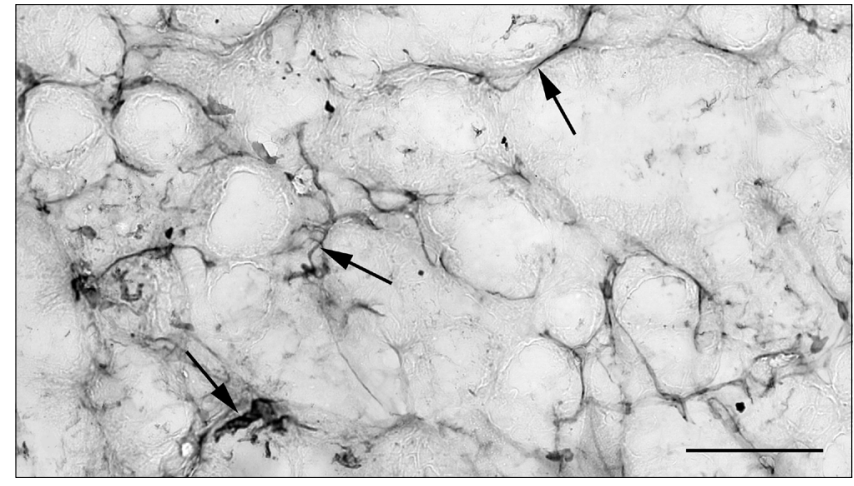

1. ábra: Glandula radicis linguae kontroll állatból. Nyilak jelzik a VIP tartalmú idegrostokat a mirigyállományban. Lépték $=100 \mu \mathrm{m}$

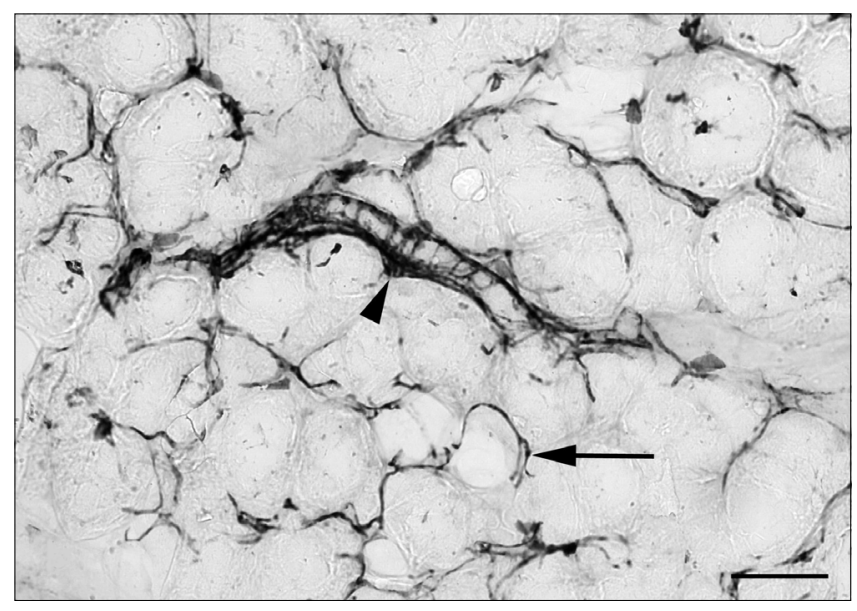

2. ábra: 2 hetes streptozotocin diabetes mellitusos állat nyelvgyök mirigyállománya.

Nyíl jelzi a mucinozus acinus körüli NPY IR idegrostot. Nyílhegy mutatja a perivascularisan található NPY pozitív idegrostokat. Lépték = $100 \mu \mathrm{m}$

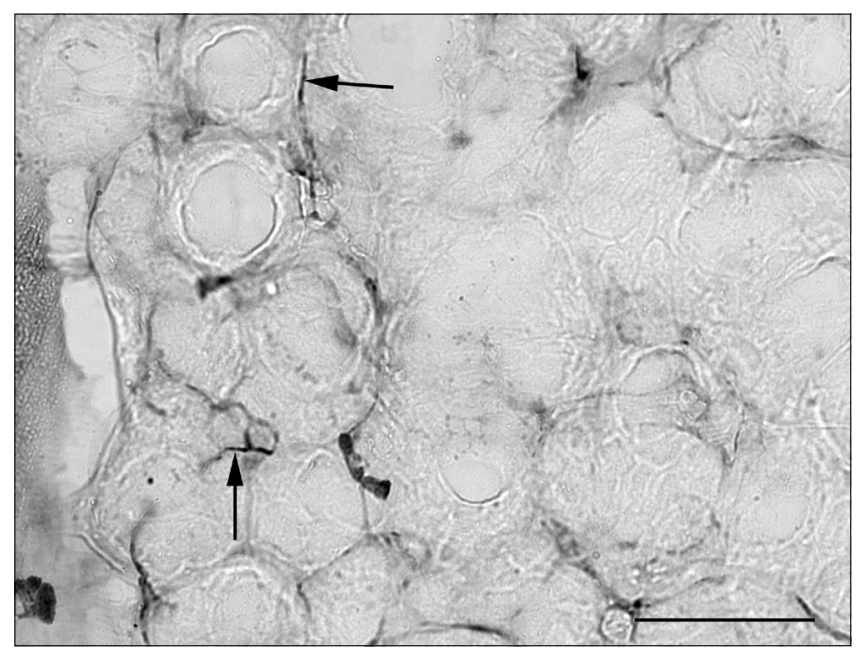

3. ábra: 4 hetes streptozotocin diabetes mellitusos állat mucinozus mirigyállománya.

Nyíl mutatja a peripherin immunoreaktív idegrostot a kivezető csövek közelében. Lépték $=100 \mu \mathrm{m}$ 


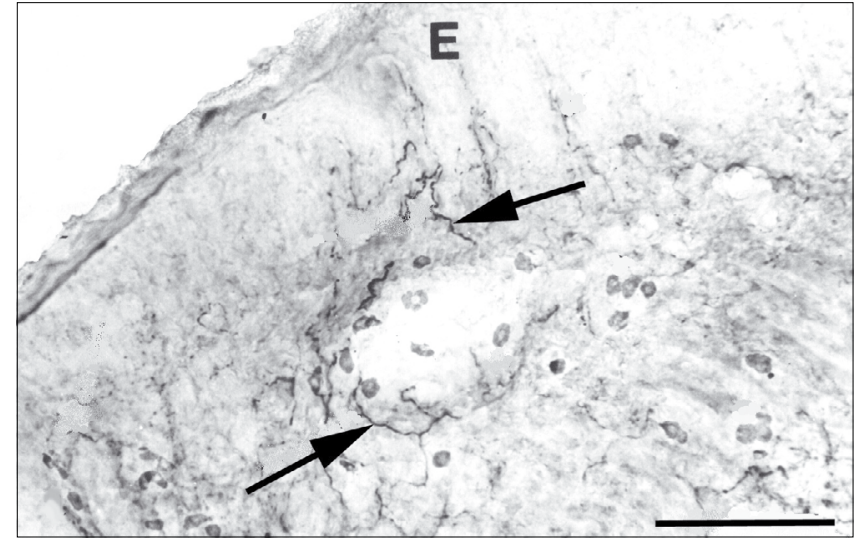

4. ábra: A P anyag tartalmú idegrostokat nyilak mutatják a kontroll állat nyelv nyálkahártyájában. Lépték $=100 \mu \mathrm{m}$

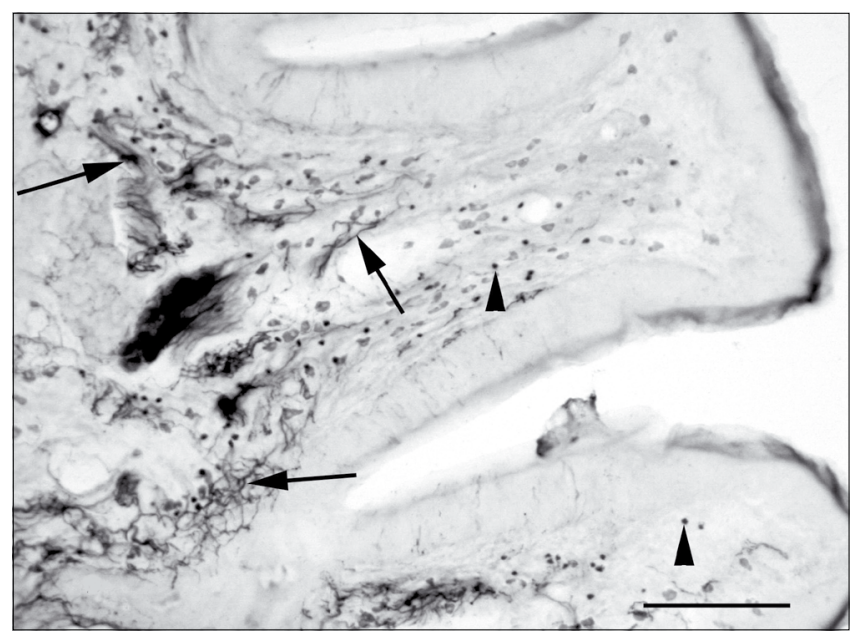

5. ábra: 2 hetes streptozotocin kezelés utáni nyálkahártya. Nyilak jelzik a $P$ anyag tartalmú idegrostokat a papilla vallata nyálkahártyájában.

Nyílhegyek mutatják a szintén $\mathrm{P}$ anyag immunpozitív limfocitákat. Lépték $=100 \mu \mathrm{m}$

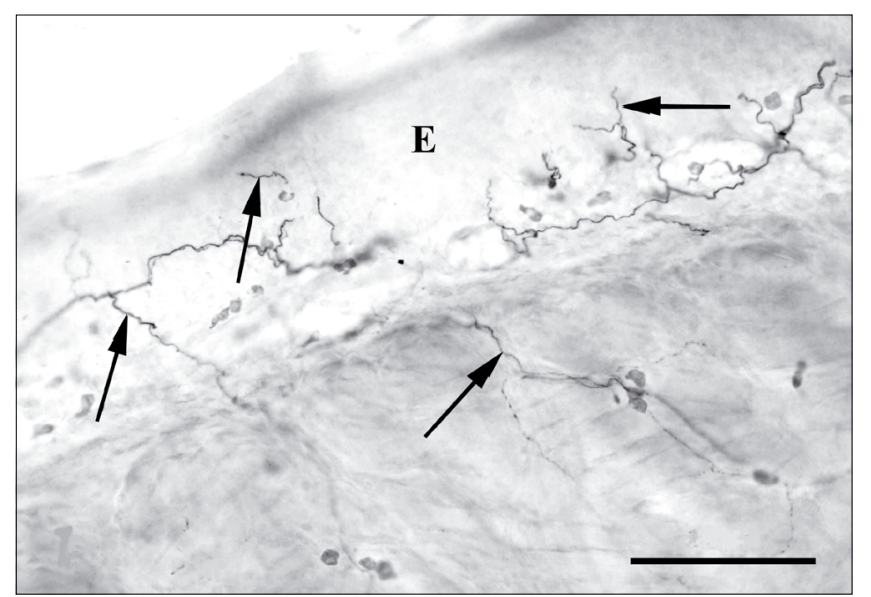

6. ábra: A peripherin (PER) pozitív idegrostokat nyíl jelzi a nyelv nyálkahártyájában 4 hetes diabetes mellitusos állatban. ( $E=$ hám) Lépték $=100 \mu \mathrm{m}$

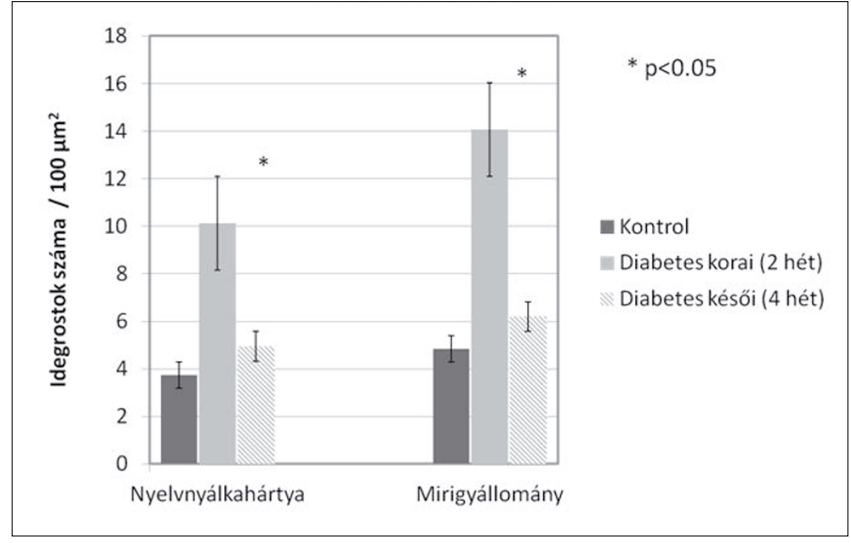

7. ábra: PER IR idegrostok mennyisége a nyelv nyálkahártyájában és mirigyállományában.

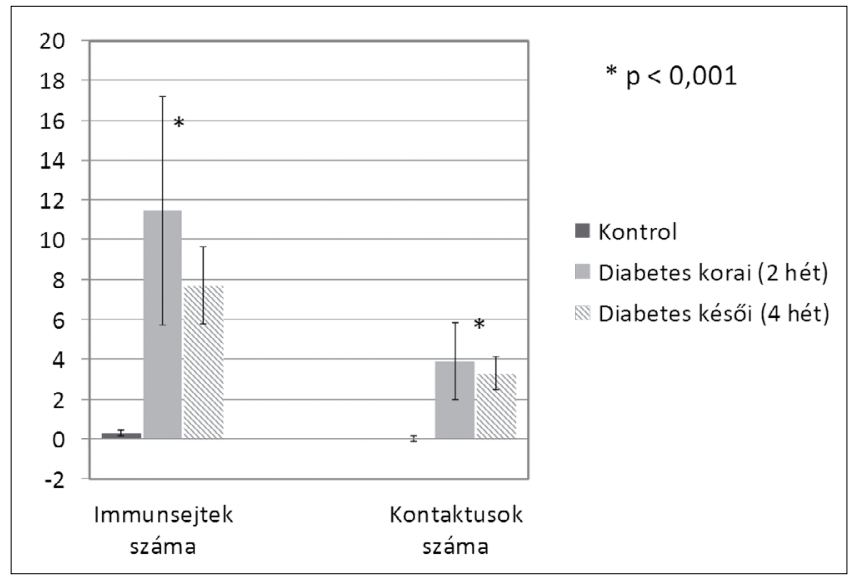

8. ábra: SP IR immunsejtek és közvetlen anatómiai kapcsolatuk az SP pozitív idegrostokkal két- és négyhetes diabetes mellitusban.

termelést kísérletes állatokban. Mivel korábban elektronmikroszkóposan bizonyítottuk a nyelvben a lokálisan záródó reflex jelenlétét (intralingualis reflex) [3], így az IR idegrostok csökkenése feltételezhetően erősen csökkenti a nyáltermelést. Egyrészt azáltal, hogy kevesebb érző (SP) rost hat a helyi ganglionok idegsejtjeire, másrészt a mirigyekben lévő szekretomotoros idegrostok (VIP, NPY) mennyisége is csökkent. A nyáltermelésben és a gyulladásos sejtek mennyiségében bekövetkezett változások szerepet játszhatnak a káriesek és a parodontális gyulladásos folyamatok kialakulásában is [22, 36]. Korábbi vizsgálatunk kimutatta, hogy a korai inzulinkezelés kivédheti az IR idegrostokban bekövetkező kóros változásokat, visszaáll az ízlelőbimbókat beidegző idegrostok eredeti mennyisége, kivédheti a csökkent ízérzést, csökkentheti a neuropátiát és a viszszaállíthatja a normál nyálelválasztást [21].

Ma már tényként elfogadott, hogy az idegrendszer és az immunrendszer sejtjei között kétirányú információcsere van [12, 15]. Az immunsejtet érő idegi hatásokat közvetítő információs utak a feltevések szerint 
több pályán és szerveződési szinten biztosítják e kétirányú kommunikációt. A legutóbbi munkánk eredményei is azt bizonyítják, hogy DM hatására szignifikánsan megemelkedik az SP idegrostok és a különböző immunsejtek száma, valamint az idegrostok és immunsejtek morfológiai kapcsolata. Különös jelentősége van ezen idegi kontaktusnak, az idegrendszer és az immunrendszer közvetlen érintkezésének, mivel a két rendszer disztansz szinaptikus kapcsolat révén gyorsan tud egymásra hatni. Neuropeptidek képesek modulálni a limfoid sejtek aktivitását, beleértve differenciálódásukat, migrációjukat, proliferációjukat, citotoxicitásukat és a mediátorok felszabadulását. Az immunsejtek viszont expreszszálják a neuropeptidek receptorait, és bizonyos stimulusok hatására neuropeptideket is termelnek. Az általuk termelt citokinek más sejtek aktivációjához, proliferációjához, differenciációjához vezetnek. Ezen sejtek számos pro-inflammatorikus és anti-inflammatorikus hatású citokineket bocsátanak ki a környezetükbe, utóbbiak igyekszenek a gyulladást eliminálni, a sebeket meggyógyítani [18, 33, 37]. DM hatására krónikusan megemelkedik a pro-inflammatoros citokinek száma, például IL-1, IL-6, TNF- $\alpha$ [7, 38]. Duarte és munkatársai [13] legújabb összehasonlító vizsgálatai kimutatták, hogy a gingivalis sulcus folyadékban lévő cito- és kemokinek mennyisége szignifikánsan nagyobb volt a DM betegeknél, még az egészséges fogaknál is, összehasonlítva a nem diabeteses betegekkel. A legutóbbi irodalmi adatok azt is bizonyítják, hogy kapszaicin kezelés hatására, ami csökkenti a $P$ anyag mennyiségét a szövetekben, vagy $P$ anyag antagonistákkal sikerült a kolitises betegeket gyógyítani és lecsökkent a TNFa szekréciója a nyálkahártya hízósejtjeiből $[8,17,35]$. Így a cukorbetegek szájüregi sebeinek, gyulladásainál az általánosan elfogadott terápia mellett szóba jöhet a jövőben a megemelkedett neuropeptidek és citokinek gátlása is, így például SP antagonisták, vagy TNFa ellenanyag alkalmazása.

\section{Irodalom}

1. Adegathe E: Distribution of calcitonin-gene-related peptide, neuropeptide-Y, vasoactive intestinal polypeptide, cholecystokinin-8, substance $\mathrm{P}$ and islet peptides in the pancreas of normal and diabetic rats. Neuropeptides 1999; 33: 227-235.

2. Albrecht M: Fog- és szájbetegségek diabetes mellitusban. Medicina könyvkiadó, Budapest, 2001.

3. Altdorfer K, Zelles T, Pongor É, Fehér E: Morphological evidence of local reflex arc in the rat's tongue. Acta Physiol Hung 2012, 99, 479-488.

4. Bastos AS, Leite ar, Spin-Neto R, Nassar po, Maussaco EM, OrRICo SR: Diabetes mellitus and oral mucosa alteration: prevelance and risk factors. Diabetes Res Clin Pract 2011, 92, 100-105.

5. Batbayar B, Zelles T, Vér Á, Fehér E: Plasticity of the different neuropeptide-containing nerve fibres in the tongue of the diabetic rat. J Periph Nerv Syst 2004, 9, 215-223.

6. Bell GW, Large DM, Barclay SC: Oral health care in diabetes mellitus SADJ 2000, 55, 58-65.
7. Bogdanski P, Pupek-Musialik D, Dytfeld J, Jagodzinski PP, JablleCKA A, KUJAWA A, MusiaLIK K: Influence of insulin therapy on expression of chemokine receptor CCR5 and selected inflammatory markers in patients with type 2 diabetes mellitus. Int $J$ Clin Pharmacol Ther 2007, 45, 563-567.

8. Castagliuolo I, Keates ACM, Qu BM, Kelly CP, Nikulasson S, LeEmam SA, Pothoulakis C: Increased substance $P$ responses in dorsal root ganglia and intestinal macrophages during Clostridium difficile toxin A enteritis in rats. Proc Natl Acad Sci USA 1997, 94, 4788-4793.

9. Christianson JA, RiekHof JT, Wright DA: Restorative effects of neutrophin treatment on diabetes-induced cutaneous axon loss in mice. Exp Neurol 2003, 179, 188-199.

10. Diabetes Atlas. International Diabetes Federation. 5th edition. IDF, Brussels, Belgium, 2011.

11. Dimel LT, Brewster WJ, Fernyhough P, Tomlinson DR: Expression of neuropeptides in experimental diabetes; effects of treatment with nerve growth factor or brain-derived neurotrophic factor. Molecular Brain Res 1994; 21: 171-175.

12. Downing JE, MIYAN JA: Neural immunoregulation: emerging roles for nerves in immune homeostasis and disease. Immunol Today 2000; 21: 281-289.

13. Duerta PM, Bezerra JP, Miranda TS, Feres M, Cambrone L, ShadDox LM: Local levels of infammatory mediators in uncontrolled type 2 diabetic subjects with chronic peridontitis. J Clin Periodontol 2013 Oct 6. DOI 10.1111/JCPE.12179.

14. ElENKOv U: Neurohormonal-cytokine interactions: implications for inflammation, common human diseases and well-being. Neurochem Int 2008, 52, 40-51.

15. Elenkov IJ, Wilder RL, Chrousos GP, VizI ES: The sympathetic nerve - an integrative interface between two supersystems: the brain and the immune system. Pharmacol Rev 2000; 52: 595-638.

16. Fehér E, Pongor É, Altdorfer K, Kóbori L, Lengyel G: Neuroimmunomodulation in human autoimmune liver disease. Cell Tissue Res 354, 543-550, 2013.

17. Gad M, Pedersen AE, Kristensen NN, Fernandez CF, Claesson MH: Blockade of the neuroinin 1 receptor and capsaicin-induced ablation of the enteric afferent protect SCID mice against T cell-induced chronic colitis. Inflamm Bowel Dis 2009, 15, 1174-1182.

18. Guest CB, Park MJ, Johnson DR, Freund GG: The implication of proinflammatory cytokines in type 2 diabetes. Front Biosci 2008 , 13, 5187-5194.

19. Ganns E, Schrödl F, Neunuber W, Brehmer A: Investigation of general and cytoskeletal markers to estimate numbers and proportions of neurons in the human intestine. Histol Histopathol 2006, 21, 41-51.

20. Györffy A, Fazekas Á. Fehér E, Ender F, Rosivall L: Effects of streptozotocin-induced diabetes on neurogenic inflammation of gingivomucosal tissue in rat. J Periodont Res 1996, 31, 249-255.

21. Hevér H, Altdorfer K, Zelles T, Batbayar B, Fehér E: Ízlelóbimbók beidegzésének változása diabetes mellitusban patkányban. Orv Hetil 2013; 154, 443-448.

22. Khader YS, Dauod AS, El-Qaderi SS, Alkafjel A, Batayha WQJ: Periodontal status of diabetics compared with nondiabetics: a metaanalysis. J Diabetes Compications 2006, 20, 59-25.

23. MARFURT CF, ECHTENKAMP SF: The effect of diabetes on neuropeptide content in the rat cornea and iris. Invest Ophthalmol Vis Sci 1995; 36, 1100-1106.

24. Karanth SS, Spingall DR, Francavilla S, Mirrlees DJ, Polak JM: Early increase in CGRP and VIP-immunoreactive nerves in the skin of streptozotocin-induced diabetic rats. Histochemistry 1990; 94, 659-666.

25. Kispélyi B, Lohinal Z., Altdorfer K, Fehér E: Neuropeptide analysis on oral mucosa of diabetic rats. Neuroimmunomodulation 2014; 21, 213-220.

26. LUGER TA: Neuromediators - a crucial component of the skin immune system. J Dermatol Sci 2002, 30, 87-93. 
27. Milner P, Appenzeller O, Qualls C, Burnstock G: Differential vulnerability of neuropeptides in nerves of the vasa nervorum to streptozotocin-induced diabetes. Brain Res 1992; 574: 56-62.

28. Moore HN, Frew ID: Peripheral vascular lesion in diabetes mellitus. Br Med J 1965; 2: 19-23.

29. Negrato CA, Tarzia O: Buccal alterations in diabetes mellitus. Diabetology and Metabolic Syndrome 2010; 2: 3 DOI 10.1186/ 1758-5996-2-3.

30. Parker RC, Rapley JW, Isley W, Spencer P, Killow WI: Gingival cervicular blood flow for assessment of blood glucose in diabetic patients. J. Periodontol 1993; 4, 666-672.

31. Parkhouse N, LE Quesme PM: Impaired neurogenic vascular response in patients with diabetes and neuropathic for lesions. New Engl J Med 1988; 318: 1306-1309.

32. Pradhan L, Nabzdyk C, Andersen N, Logrefo FW, Veves A: Inflammation and neuropeptides: The connection in diabetic wound healing. Expert Rev Mol Med 2013; 1:e2. DOI 10.1017/ S1462399409000945.

33. RICHES DWH: Macrophage involvement in wound repair, remodeling and fibrosis. 2nd edition, London: Plenum New York, 1996.

34. SAINI R, AL-Maweri SA, SaINI D. Ismail NM, Ismail AR: Oral mucosal lesions in non oral habit diabetic patients and association of diabetes mellitus with oral precancerous lesions. Diabetes Res Clin Pract 2010; 89: 320-326.

35. Sonea JM, Palmaer MV, AKILII D, Harp JA: Treatment with neurokinin-1 receptor antagonist reduces severity of inflammatory bowel disease induced by Cryptospodium parvum. Clin Diagn Lab Immunol 2002; 9: 333-340.
36. Southerland JH, Taylor G, Offendacher S: Diabetes and periodontal infection: making the connection. Clin Diabetes 2005; 23: 171-178.

37. Sunderkotter $\mathrm{C}$, Steinbrink K, Goebeler M, Bhardwaj R, Sorg C: Macrophages and angiogenesis. J Leukoc Biol 1994; 55: 410-422.

38. TILG H, MOSCHEN AR: Inflammatory mechanisms in the regulation of insulin resistence. Mol Med 2008; 14: 222-231.

39. Troger J, Humpel C, Kremser B, Kralinger M, Teuchner B, Kunze C, PhILIPP W, KIESELBACH G: The effect of streptozotocin-induced diabetes mellitus on substance $P$ and calcitonin gene-related peptide expression in the rat trigeminal ganglion. Brain Res 1999; 842: 84-91.

40. Újpál M, Matos O, Bíвok $\mathrm{G}$, Szabó $\mathrm{G}$ : A diabetes mellitus előfordulása malignus szájüregi daganatos betegekben. Orv Hetil 2002; 143: 2731-2733.

41. Újpál M, Matos O, Вíbok G, Somogy A, Szabó G, Suba Z: Diabetes and oral tumors in Hungary. Diabetes care 2004; 27: 770-774.

42. Willars GB, Calcutt nA, Compton AM, Tomlinson DR, Keen P Substance $P$ levels in peripheral nerve, skin atrial myocardium and gastrointestinal tract of rats with long term diabetes mellitus. Effect of aldose reductase inhibition. J Neurol Sci 1989; 91: 153-164.

43. WISOCKI GP, DALEY TD: Benign migratory glossitis in patients with juvenile diabetes. Oral Surg Oral Med Oral Pathol 1987; 63: 68-70.

44. Yuan A, Sasaki T, Kumar A, Peterhoff CM, Rao MV, Liem RK, JuLIEN JP, NIXON A: Peripherin is a subunit of peripheral nerve neurofilament: implications for differential vulnerability of CNS and PNS axons. J Neurosci 2012; 32: 8501-8508.

\section{Kispélyı B, Altdorfer K, Fehér E}

\section{Changes of the innervation in the mucous membrane and glands of the tongue in diabetes mellitus}

The number of the different neuropeptides-containing nerve fibres and immunocompetent cells was changed in diabetes mellitus (DM) in different organs. In this work we investigated the effect of DM on quantitation of the nerve fibres using immunhistochemistry. After two weeks of the DM the quantitiy of the different nerve fibres increased significantly both in the mucous membrane and glands of the tongue. The number of the immunocompetent cells (lymphocytes, plasma cells, mast cells) increased as well significantly. Some of these cells showed also immunoreactivity for substance $P$ and neuropeptide $\mathrm{Y}$. A few substance $\mathrm{P}$ cells were in very close relation to the SP immunoreactive nerve fibres. After four weeks of DM the number of the nerve fibres was decreased compared to the 2 weeks treatment, however, the number of them was higher compared to the control. The close relation between the nerve fibres and immunocells might play a crutial role in maintaining the homeostasis the mucous membrane and glands of the tongue as well as in the increasing inflammation and elimination of it.

Key words: Substance $\mathrm{P}$, Neuropeptid $\mathrm{Y}$, mucous membrane of the tongue, neuroimmunomodulation 